\title{
Unusual HBV Mixed Genotype Infections Among Hepatitis Type B Iraqi Patients in Wasit Province/Iraq
}

\author{
Ali Shakir Kamil Al-Suraifi ${ }^{1}$, Ahmed Darwish Jabbar Al-Rubaie ${ }^{1}$, \\ Sareaa Maseer Gatya Al-Mayahie ${ }^{1, \text {, }}$, Naeem Mohammed Mohsen Al-Abedy ${ }^{2}$ \\ ${ }^{1}$ Department of Biology, College of Science, Wasit University, Al-Kut, Iraq \\ ${ }^{2}$ Molecular Biology Laboratory, Alkarama Teaching Hospital, Al-Kut, Iraq
}

Email address:

sareaamaseer@gmail.com (S. M. G. Al-Mayahie)

${ }^{*}$ Corresponding author

To cite this article:

Ali Shakir Kamil Al-Suraifi, Ahmed Darwish Jabbar Al-Rubaie, Sareaa Maseer Gatya Al-Mayahie, Naeem Mohammed Mohsen Al-Abedy. Unusual HBV Mixed Genotype Infections Among Hepatitis Type B Iraqi Patients in Wasit Province/Iraq. International Journal of Biomedical Engineering and Clinical Science. Vol. 2, No. 1, 2016, pp. 1-7. doi: 10.11648/j.ijbecs.20160201.11

Received: August 29, 2016; Accepted: November 3, 2016; Published: December 9, 2016

\begin{abstract}
Hepatitis B virus (HBV) is the leading cause to liver disease, cirrhosis and primary liver cancer. About 1 million people die from HBV each year, which equates to about $2 \mathrm{HBV}$ related deaths each minute. Depending on the virus sequence homogeneity as a minimum 10 genotypes (A to $\mathrm{J}$ ) and numerous subgenotypes have been identified. Hepatitis B virus variants may be differ in their virulence, models of serologic reactivity, pathogenicity, response to treatment and global distribution. This study was carried out to detect HBV genotypes among Iraqi hepatitis type B patients in Wasit Province/ Iraq using nested PCR protocol. A total of 105 outpatients (65 males and 40 females, aged 1-95 years) clinically suspected as having viral hepatitis were included in this study. All the patients' sera (105 samples) were positive for HBV surface antigen (HBsAg) by ELISA screen test. Whereas $72(60.5 \%)$ and $33(31.4 \%)$ of these samples were positive and negative for HBV DNA, respectively, by first PCR. Survey of DNA positive samples for HBV genotypes by nested PCR (second PCR) demonstrated a unique results that no single genotype was found and all of these samples had mixed genotypes of which the pattern $\mathrm{A}+\mathrm{B}+\mathrm{C}+\mathrm{D}+\mathrm{E}$ was the most common $(77.7 \%)$, followed by $\mathrm{A}+\mathrm{B}+\mathrm{D}+\mathrm{E}(16.66 \%), \mathrm{A}+\mathrm{B}+\mathrm{C}(2.77 \%), \mathrm{A}+\mathrm{B}+\mathrm{E}(1.38 \%)$, and $\mathrm{A}+\mathrm{D}+\mathrm{E}(1.38 \%)$, whereas genotype $\mathrm{F}$ was not found in any patient. Statistically, there was non-significant difference in distribution of genotypes among males and females. The presence of mixed infection with about 5 HBV genotypes among most of our patients lead us to conclude that these patients are incurred to different sources of infection at different times and this required an epidemiological evaluation of HBV infection among our patients not only in Wasit Province but also all over Iraq to control this abnormal acquisition of these genotypes by Iraqi people.
\end{abstract}

Keywords: HBV, Genotypes, Wasit Province, Iraq

\section{Introduction}

Hepatitis B virus (HBV) is a causative agent of significant infectivity and death around the world [1]. About 2 billion of human beings have been infected with $\mathrm{HBV}$ and $>240$ millions suffering from chronic hepatitis $\mathrm{B}$ (CHB), while 600,000 of patients pass through acute hepatitis B (AHB) and $\mathrm{CHB}$ yearly [2]. According to a global surveys more populations die in a day from CHB than AIDS in 1 year and yearly 1 million of peoples die from $\mathrm{HBV}$ related viral illnesses [3].
Eight genotypes of HBV were classified depending on difference in $>8 \%$ of total HBV genome (A-H), some of them separate into sub genotypes with genetic difference of $4 \%$ 8\%. Also, 2 genotypes were newly identified (I and J) [4]. These genotypes have been shown to have a distinct geographic distribution [5]. Genotype A is found mainly in North America and Northwest Europe [6]. B and C genotypes are highly prevalent in Australia and Asia [7]. Genotype D is worldwide in distribution with highest prevalence in the 
Middle East and Southern Europe, genotype E is almost entirely restricted to West Africa, F genotype in Central and South America [8]. Genotype $G$ has been reported in the United States, Germany and France [9]. Genotype H was recently identified in patients from Central America [10]. Genotype I was reported in Italy, Laos and Vietnam, while the newest genotype $\mathrm{J}$ has been recognized in Ryukyu island in Japan [4].

Hepatitis B virus genotyping is an important technique to explain the way and pathogenesis of the virus [11, 12]. In Iraq, several studies on HBV prevalence and genotyping were carried out, whereas In Wasit Province, to our knowledge, there is no previous study dealing with genotyping of HBV, so that this study was conducted for molecular detection of $\mathrm{HBV}$ and determination of this virus genotypes (A-F) using nested PCR protocol.

\section{Materials and Methods}

\subsection{Patients}

A total of 105 patients clinically suspected as having viral hepatitis were enrolled in this study. Of these patients, 40 were females (aged 13-95 years) and 65 were males (aged 173 years). These patients were outpatients attending Alkarama Teaching Hospital and Central Health Laboratory in AL-Kut City/Wasit Province/Iraq during the period from1 October 2015 to 15 February 2016. Each patient's information included only gender and age. Unfortunately, we couldn't obtained any information about the history of infection, treatment, and other family members' infection as a result of inability to meet these patients and inavailability of patients' records in these hospitals.

No formal ethical approval was obtained to use the clinical samples, because they were collected during routine laboratory analyses in public hospital and the data were anonymously analyzed. This work was approved by Wasit Health Administration/ Wasit Province/ Iraq. Therefore, consent from the patients was not required.

\subsection{Specimen Collection and Processing}

From each patient single blood sample $(5 \mathrm{ml})$ was drawn by venepuncture using sterile $5 \mathrm{ml}$ syringe. The blood was located in clean tube and the tubes were left to stand at room temperature $\left(18-25^{\circ} \mathrm{C}\right)$ for 15 minutes to coagulate. Serum was separated from blood by centrifugation at $3000 \mathrm{rpm}$ for 5 minutes and divided into aliquots of $(300 \mu \mathrm{l})$ and stored at $20^{\circ} \mathrm{C}$ till use. Every aliquot of serum was used one time to avoid sample decay because of repeating freezing and thawing cycles.

\subsection{ELISA Screen Test for HBsAg}

Serum samples were added according to the designation on the ELISA working sheet (CTK, USA).

\subsection{Nested PCR for HBV Detection and Genotyping}

Detection of HBV DNA and genotypes was accomplished by nested PCR according to Naito et al. [11] using specific primers. The following steps were carried out:

\subsubsection{Extraction of $\mathrm{HBV} \mathrm{DNA}$}

DNA extraction was done according to the manufacturer's instructions (Anatolia gene work, Turkey).

\subsubsection{Detection of HBV DNA by First PCR}

Hepatitis B virus DNA was detected by the amplification of pre-S1 through $\mathrm{S}$ gene by using universal primers for genotypes A-F (Table 1). The total volume of the reaction mixture was $50 \mu \mathrm{l}: 43 \mu \mathrm{l}$ sterile distilled water, $1 \mu \mathrm{l}(25$ pmole) each of P1 and S1-2 primers, and $5 \mu$ of DNA sample, all of which were added to the tube of lyophilized master mix (Bioneer, Korea), then the mixture was centrifuged at $8000 \mathrm{rpm}$ for 1 second.

Thermal cycler was programmed to first incubate the samples for $10 \mathrm{~min}$ at $95^{\circ} \mathrm{C}$, followed by 40 cycles consisted of $94^{\circ} \mathrm{C}$ for $20 \mathrm{~s}, 55^{\circ} \mathrm{C}$ for $20 \mathrm{~s}$, and $72^{\circ} \mathrm{C}$ for 1 min and final extension at $72^{\circ} \mathrm{C}$ for 10 minutes. PCR products were electrophoresed in a $2 \%$ agarose gel and stained with ethidium bromide. The PCR bands were then visualized by UV light. Positive samples of first product were estimated according to the migration pattern of 100 bp DNA ladder.

\subsubsection{Detection of HBV Genotypes by Second PCR}

The six nested PCR primers for HBV genotypes A-F (Table 1) were made up according to the conserved nature of the nucleotide sequence in the pre-S1 regions through $\mathrm{S}$ gene. The genotypes of HBV were determined based on the differences in the size of the amplified DNA bands.

Two second-round nested PCRs were performed for each sample product from the first PCR. mix A, for the identification of genotypes $\mathrm{A}, \mathrm{B}$ and $\mathrm{C}$ with the common universal sense primer (B2). Mix B to identify genotypes D, E and F. A $1 \mu$ l of first PCR product was added to each of mix A and mix B. The reaction mixture of mix A was made up of master mix (Bioneer, Korea), $43 \mu 1$ of sterile distilled water, $1 \mu \mathrm{l}$ (25 pmole) of each of BA1R, BB1R, BC1R, $3 \mu 1$ of B2 (the universal sense primer) and $1 \mu \mathrm{l}$ of the first PCR product. Mix B was made up of master mix (Bioneer, Korea), $43 \mu \mathrm{l}$ sterile distilled water, $1 \mu \mathrm{l}(25$ pmole $)$ of each of BD1, BE1, BF1, $3 \mu$ l of the universal antisense primer $\mathrm{B} 2 \mathrm{R}$, and $1 \mu \mathrm{l}$ of the first round PCR product. The second PCRs were applied for 40 cycles with the following parameters: preheating at $94^{\circ} \mathrm{C}$ for $10 \mathrm{~min}, 20$ cycles of amplification at $94^{\circ} \mathrm{C}$ for $20 \mathrm{~s}, 58^{\circ} \mathrm{C}$ for $20 \mathrm{~s}$, and $72^{\circ} \mathrm{C}$ for $30 \mathrm{~s}$, and additional 20 cycles of $94^{\circ} \mathrm{C}$ for $20 \mathrm{~s}, 60^{\circ} \mathrm{C}$ for $20 \mathrm{~s}$, and $72^{\circ} \mathrm{C}$ for $30 \mathrm{~s}$. Nested PCR products were identified by electrophoresis at a $2.5 \%$ agarose gel and stained with ethidium bromide. The bands were evaluated under UV light transilluminator. The size of the product bands was estimated according to the migration pattern of $25 \mathrm{bp}$ DNA ladder. 
Table 1. Primers' sequences of $6 \mathrm{HBV}$ genotypes [11].

\begin{tabular}{|c|c|c|}
\hline PPrimername & Sequence $^{\text {a }}$ (specificity, position, and polarity) & Amplified productsize (bp) \\
\hline \multicolumn{3}{|l|}{ FirstPCR } \\
\hline $\mathrm{P} 1^{b}$ & 5'-TCACCATATTCTTGGGAACAAGA-3'(universal,sense) & \multirow{2}{*}{1063} \\
\hline S1-2 & 5'-CGAACCACTGAACAAATGGC-3'(universal,antisense) & \\
\hline \multicolumn{3}{|l|}{ SecondPCR } \\
\hline \multicolumn{3}{|l|}{ MixA } \\
\hline B2 & 5'-GGCTCMAGTTCMGGAACAGT-3'(typesAtoEspecific,sense) & \\
\hline BA1R & 5'-CTCGCGGAGATTGACGAGATGT-3'(typeAspecific,antisense) & 68 \\
\hline $\mathrm{BB} 1 \mathrm{R}$ & 5'-CAGGTTGGTGAGTGACTGGAGA-3'(typeBspecific,antisense) & 281 \\
\hline $\mathrm{BC} 1 \mathrm{R}$ & 5'-GGTCCTAGGAATCCTGATGTTG-3'(typeCspecific,antisense) & 122 \\
\hline \multicolumn{3}{|l|}{ MixB } \\
\hline BD1 & 5'-GCCAACAAGGTAGGAGCT-3'(typeDspecific,sense) & 119 \\
\hline BE1 & 5'-CACCAGAAATCCAGATTGGGACCA-3'(typeEspecific,sense) & 167 \\
\hline BF1 & 5'-GYTACGGTCCAGGGTTACCA-3'(typeFspecific,sense) & 97 \\
\hline $\mathrm{B} 2 \mathrm{R}$ & 5'-GGAGGCGGATYTGCTGGCAA-3'(typesDtoFspecific,antisense) & \\
\hline
\end{tabular}

${ }^{a} \mathrm{An}$ "M" a nucleotide that may be either an A or C; a "Y" a nucleotide that may be either C or T.

\subsection{Statistical Analysis}

Statistical analysis was accomplished according to Ross [13] using Chi-square test $(\chi 2)$, this statistical method was used to detect the significant statistical relationship between variables and the results being considered as statistically significant when a p-value was less than 0.05 .

\section{Results}

Patients' survey for $\mathrm{HBs} \mathrm{Ag}$

In this study 105 patients, clinically suspected as having HBV infection, firstly were surveyed for HBsAg by ELISA screen test to diagnose their infection with HBV. All of these patients (100\%) were positive for HBsAg (Table 2).

Table 2. ELISA screen test for HBsAg among 105 patients.

\begin{tabular}{lllc}
\hline Gender & No. of samples & No. of positive samples & $\%$ \\
\hline Male & 65 & 65 & 100 \\
Female & 40 & 40 & 100 \\
Total & 105 & 105 & 100 \\
\hline
\end{tabular}

PCR detection of HBV DNA

This study included 105 samples which were tested by PCR technique for HBV DNA by using type specific primers (Figure 1). Seventy two samples (60.5\%) were positive for HBV DNA, while 33 (31.4\%) were negative (Table 3).

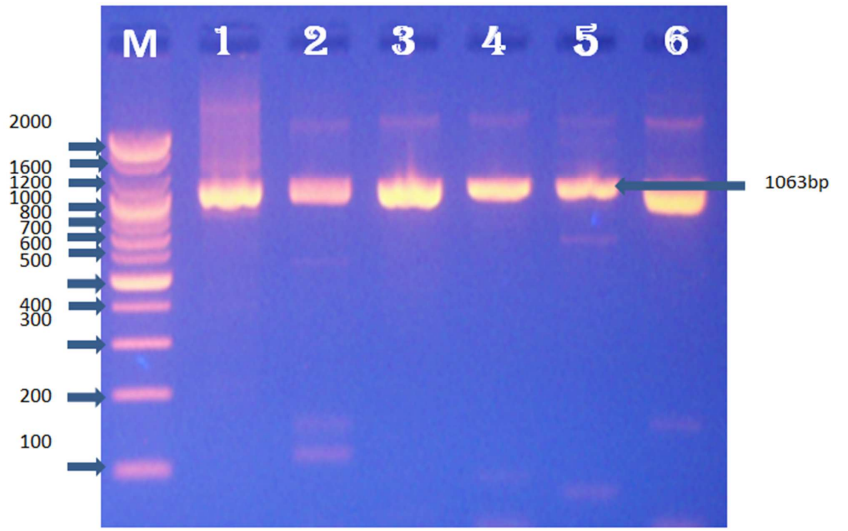

Figure 1. Agarose gel electrophoresis of first PCR products for HBV DNA using 2\% agarose gel and 100 volt for 60 minutes. M: 100bp DNA marker, lanes (1-6) positive samples for HBV DNA giving a band of 1063bp.

Table 3. Detection of HBV DNA by PCR technique using specific primers among 105 patients.

\begin{tabular}{llll}
\hline Gender & No. of samples & No. of positive samples & $\%$ \\
\hline Male & 65 & 65 & 100 \\
Female & 40 & 40 & 100 \\
Total & 105 & 105 & 100 \\
\hline
\end{tabular}

A unique results were detected in this study, that no single genotype was determined and all of these samples showed mixed infection of genotypes (Figure $2 \mathrm{~A}$ and B). The percent distribution of $\mathrm{HBV}$ genotypes among our patients were as follows: $\mathrm{A}+\mathrm{B}+\mathrm{C}+\mathrm{D}+\mathrm{E} \quad(77.77 \%), \quad \mathrm{A}+\mathrm{B}+\mathrm{D}+\mathrm{E} \quad(16.66 \%)$, $\mathrm{A}+\mathrm{B}+\mathrm{C}(2.77 \%), \mathrm{A}+\mathrm{B}+\mathrm{E}(1.38 \%), \mathrm{A}+\mathrm{D}+\mathrm{E}(1.38 \%)$, whereas genotype $\mathrm{F}$ was not found in any patient. 


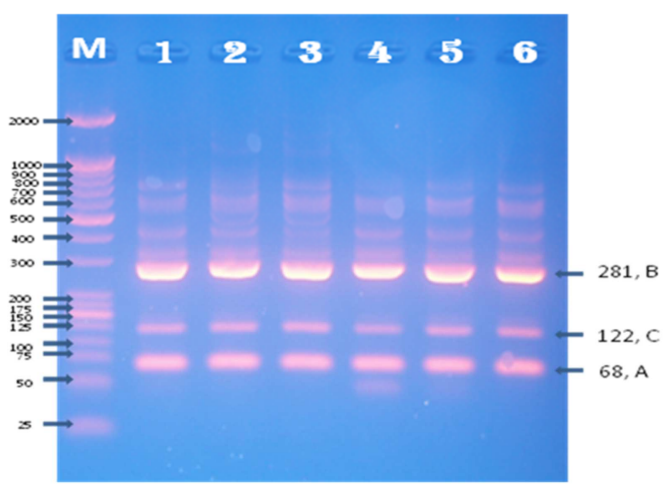

A. Mix A for types A (68bp), B (281bp), and C (122bp). Lanes 1-6: positive samples for infection with mixed genotypes $\mathrm{A}+\mathrm{B}+\mathrm{C}$.

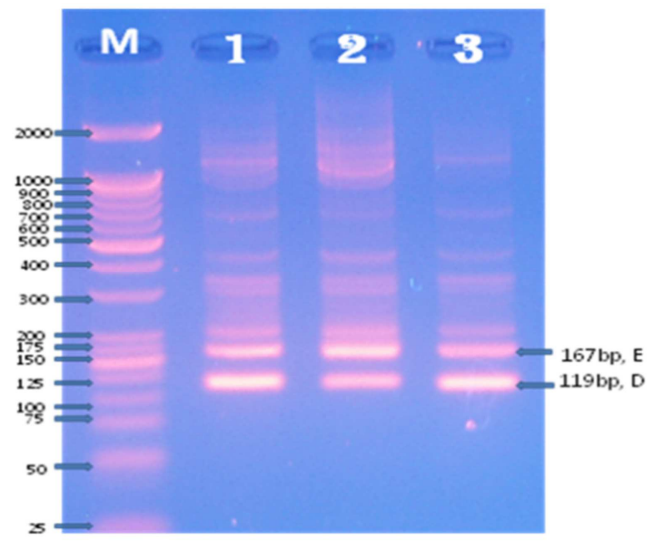

B. Mix B for types D (119bp), E (167bp), and F (97bp). Lanes 1-3: positive samples for mixed infection with genotypes $\mathrm{D}$ and $\mathrm{E}$.

Figure 2. Gel electrophoresis results of second PCR amplification step in the nested PCR for HBV genotyping using 2.5\% agarose gel and 100 volt for 60 minutes. Lane M: represent 25 bp DNA ladder.

In order to certify that these bands were not primer dimmer or unspecific bands due to presence of several primers in the mixture, the specific genotypes primers (mix A) set were put individually in the PCR mixture for the same sample (positive sample for genotypes $\mathrm{A}+\mathrm{B}+\mathrm{C}$ ) to perform simplex PCR. The results showed bands of the same expected size for each HBV genotype as in the multiplex PCR (Figure 3).

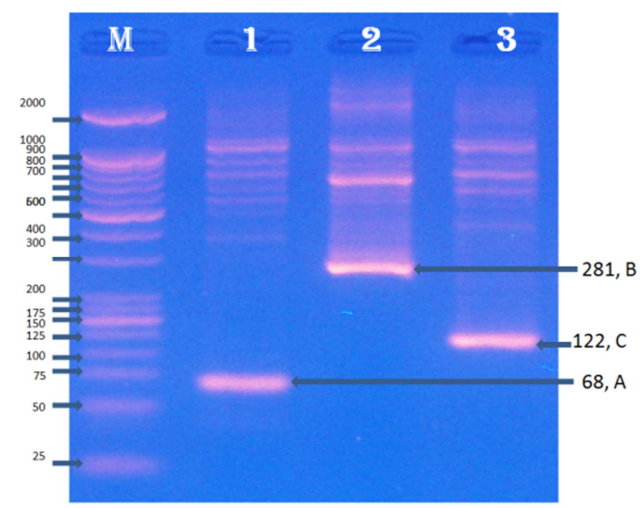

Figure 3. Gelelectrophoresis of second PCR (single primer set, specific for $H B V$ genotypes: $A, B$, and $C$ ) amplification step in the nested PCR for $H B V$ genotyping using 2.5\% agarose gel and 100 volt for 60 minutes. Lane $M$ represents $25 \mathrm{bp} D N A$ ladder, Lanes 1, 2, and 3 represent genotypes $A, B$, and $C$, respectively.
Among this study included patients, mixed infection with five genotypes $(\mathrm{A}+\mathrm{B}+\mathrm{C}+\mathrm{D}+\mathrm{E})$ was the most predominant ((77.7\%: $92 \%$ for females and $70.2 \%$ for males), followed by genotypes $\mathrm{A}+\mathrm{B}+\mathrm{D}+\mathrm{E}(16.6 \%)$. Genotypes $\mathrm{A}+\mathrm{B}+\mathrm{C}$ were not detected in females while $2(4.2 \%)$ were detected in male patients (Table 4). The less prevalent mixed genotypes detected were $\mathrm{A}+\mathrm{B}+\mathrm{E}$ ( $4 \%$ in females versus 0 in males) and $\mathrm{A}+\mathrm{D}+\mathrm{E}$ ( 0 in females versus $2.1 \%$ in males). Statically there was non-significant difference in distribution of genotypes among males and females.

Table 4. Genotypes of HBV detected by nested PCR among 72 HBV patients.

\begin{tabular}{llll}
\hline \multirow{2}{*}{ Genotypepattern } & \multicolumn{3}{l}{ No.(\%) of positivesamples } \\
\cline { 2 - 4 } & Females(n=25) & Males(n=47) & Total(n=72) \\
\hline A+B+C+D+E & $23(92)$ & $33(70.2)$ & $56(77.7)$ \\
A+B+D+E & $1(4)$ & $11(23.4)$ & $12(16.6)$ \\
A+B+C & $0(0)$ & $2(4.2)$ & $2(2.7)$ \\
A+B+E & $1(4)$ & $0(0)$ & $1(1.3)$ \\
A+D+E & $0(0)$ & $1(2.1)$ & $1(1.3)$ \\
P-Value $=0.133$ & & & \\
\hline
\end{tabular}

\section{Discussion}

As there was no previous study for HBV genotyping in Wasit Province/Iraq, this study was achieved for this purpose. Firstly, all this study included patients $(n=105)$ were positive for HBsAg which indicated that they are all infected with HBV as this antigen is considered the key of HBV serological markers in diagnosis and detection of the infection. It is an important envelope protein which appears after short time of infection; HBsAg can be detected during three to four weeks after the first time of infection and might be reach to five months in acute infection [14]. It is the initial antigen appears following $\mathrm{HBV}$ infection. When HBsAg continues greater than six months, this is an indication of CHB infection [15]. In other studies $[16,17]$ that were carried out in Iraq it was shown that $44.52 \%$ and $49.7 \%$ of $\mathrm{HBV}$ infected patients were positive for HBsAg, respectively. Also, Al-Aboudi and Al-Hmudi [18] reported that $28.5 \%$ of patients were positive for $\mathrm{HBsAg}$ whereas $24.2 \%$ of recovery patients were positive for this antigen. In Egypt, Khaled et al. [19] studied $140 \mathrm{HBV}$ Egyptian patients and found that all of them were positive for HBsAg. In Iran, Ghafourian et al. [20] showed that among 58 of CHB patients $55(94.8 \%)$ were positive for HBsAg. Weber et al. [21] demostrated that HBsAg may be undetectable (negative) in the early phase of infection but in CHB infected patients, HBsAg marker can be permanently positive.

Identification of HBV by PCR using type specific primers revealed that 72 samples $(60.5 \%)$ were positive for HBV DNA, while $33(31.4 \%)$ were negative. Although, all of this study included samples $(n=105)$ were positive for HBsAg by ELISA screen test, 33 of them were negative for HBV DNA by PCR technique. This difference did not exclude the presence of infection with $\mathrm{HBV}$ in these 33 patients as $\mathrm{HBsAg}$ is considered the key of HBV serological markers in diagnosis of the infection $[14,22]$. This means that these 33 patients may be chronically infected with HBV and are in the non-replicative phase as the natural course of chronic HBV infection comprises four phases 
all of them are $\mathrm{HBsAg}(+\mathrm{ve})[23,24]$. Predominantly patients in the non-replicative phase are characterized by seroconversion of $\mathrm{HBeAg}$ to anti-HBe, very low or undetectable serum HBV DNA levels (usually $<2000 \mathrm{IU} / \mathrm{ml}$ ) and normal serum aminotransferases (approximately $40 \mathrm{IU} / \mathrm{ml}$ ) conferring a favorable long-term outcome due to immunological control of the infection $[3,25,26]$. Similar results were obtained by Khaled et al. [19] who found from $140 \mathrm{HBV}$ infected patients (all of them were positive for $\mathrm{HBsAg}$ ) only 100 patients were positive for HBV DNA.

Numerous methods of HBV genotyping have been developed of which direct sequencing of HBV genome is the mainly accurate technique [27]. Another genotyping method established was nested PCR amplification technique by using type specific primers which can recognize 6 major genotypes (A-F) of HBV [11]. As in Asia A, C and D genotypes were the most predominant [28], we concentrated in this study on detecting these 6 major genotypes among our patients using nested PCR technique developed by Naito et al. [11]. In addition, comparison of this method with other techniques of genotyping for example RFLP, this method appears to have a higher sensitivity of recognition and have high ability in distinguishing HBV genotypes. Also, the sensitivity of this method in detection of HBV DNA is $10^{2}$ copies/ml [29].

Unexpected results were obtained in this study, that no single genotype was determined and that $77.7 \%$ of the patients had mixed infection with 5 genotypes out of 6 detected in this study. This study's results were consistent with those reported from Sulaimania in Iraq [30] using the same method, where they found $100 \%$ of samples (4 HBV patients) had mixed genotypes (one with $\mathrm{B}+\mathrm{C}+\mathrm{D}$ and three with $\mathrm{A}+\mathrm{B}+\mathrm{C}+\mathrm{D}$ genotypes). Whereas, in Baghdad Ahmed [31] found that genotype D $(80 \%)$ was the predominant among CHB patients and mixed genotypes D+F (20\%) were relatively less prevalent. Also, Issa et al. [32] in Basra/Iraq detected genotype D in 24 patients and 2 of patients had mixed genotypes $(\mathrm{D}+\mathrm{E})$. Information about the prevalence of HBV genotypes in neighboring countries showed that in Saudi Arabia [33] among $70 \mathrm{HBV}$ patients: $1.4 \%$ had genotype A, $1.4 \%$ genotype C, 5.7\% genotype E and $81.4 \%$ genotype $\mathrm{D}$, whereas $10 \%$ of patients had mixed genotypes: 4 (57\%) had $\mathrm{A}+\mathrm{D}+\mathrm{G}, 1$ (14.28\%) had D+E, 1 (14.28\%) had $\mathrm{D}+\mathrm{F}$, and $1(14.28 \%)$ had $\mathrm{A}+\mathrm{D}+\mathrm{F}+\mathrm{G}$. In Egypt, Zekri et al. [34] found that 70 patients had single genotype either A or B or $\mathrm{C}$ or $\mathrm{D}$, while 11 cases had mixed genotypes: 5 (45.45\%) had $\mathrm{A}+\mathrm{D}, 2$ (18.18\%) had $\mathrm{C}+\mathrm{D}, 2(18.18 \%)$ had $\mathrm{B}+\mathrm{D}$ and 2 $(18.18 \%)$ had $\mathrm{B}+\mathrm{C}$. Moreover, Yoosefi et al. [35] in Iran studied 163 samples and found $154(94.5 \%)$ of them had genotype D and $9(5.5 \%)$ had mixed genotypes of $\mathrm{C}+\mathrm{D}$. As well as, in Pakistan, a single genotype (either A or D) was reported among 295 positive cases, whereas $9.1 \%$ of samples showed mixed infection with $\mathrm{A}+\mathrm{B}$ [12]. Chen et al. [36] recorded mixed infection of HBV genotypes in $325 \mathrm{HBV}$ infected intravenous drug users (IVDUs): genotypes $\mathrm{A}+\mathrm{B}$ in $18(5.5 \%), \mathrm{B}+\mathrm{C}$ in $30(9.2 \%), \mathrm{B}+\mathrm{D}$ in $1(0.3 \%), \mathrm{A}+\mathrm{C}$ in 1 $(0.3 \%)$ and $A+B+C$ in $3(0.9 \%)$. Mercier et al. [37] found of 191 samples: $163(85.3 \%)$ carried a single genotype, whereas
$28(14.7 \%)$ had mixed genotype infections, of 28 mixed infections 25 were double infections and 3 were triple infections. Other studies that disagreed with this study results in the nearby countries showed that $97 \%$ of patients in Syria were infected with genotype D [38]. In Turkey Genotype D represented the predominant genotype in all Turkish patients infected with HBV [39]. In another research in Turkey [40] it was reported that all 44 patients included in their study were infected with genotype D. Also, among $642 \mathrm{CHB}$ patients in China, $\mathrm{C}$ was the dominant genotype $(68.2 \%)$, followed by B (11.2\%), and D (7.2\%) [41].

Seven genotypes (A-G) were determined in Asia, of which A, C and D were the most predominant, whereas in Europe and Africa A, C, D and G genotypes were detected. Mixed genotypes $\mathrm{A}+\mathrm{C}$ and $\mathrm{C}+\mathrm{D}$ were the predominant in Asia, while $\mathrm{C}+\mathrm{D}$ in Europe and $\mathrm{A}+\mathrm{D}$ in Africa [28]. The high prevalence of mixed infections among this study included patients revealed multiple incurrence of these patients to different HBV genotypes, and indicated high endemicity of genotypes A, B, C, D, and E in our community. Worldwide, the most vulnerable individuals to mixed infection with different HBV genotypes are the IVDUs as it was reported by Chen et al. [42]. The probability of presence of IVDUs among our patients is possible, especially, $44.7 \%$ of these patients were within the young age group 21-40 years (not published data) who are more likely to be drug abusers but not investigated by us or other Iraqi researchers as talk about these subjects is not allowed socially in our community. In Iraq, drug abuse increased with the invasion of Iraq in 2003 and still a growing problem. Other possibility of the presence of mixed genotypes was recombination between genotypes as explained by Chen et al. [42] but this possibility was not investigated here. Other Iraqi researchers [30] in Northern Iraq explained that the high prevalence of mixed infections in their study may be due to "the migration of a large number of Kurdish people as refugee to Europe and America and remaining in the refugee camps for long periods, in which communication with people of different countries might cause transmission of infection with different genotypes. In addition, low level of education about the way of disease transmission in kurdistan, negligence of sterilization in the dental clinics and negligence of using disposable materials in makeup and hairdresser salons may be other predisposing factors to HBV infection in our community.

\section{Conclusion}

The presence of mixed infection in both males and females with about $5 \mathrm{HBV}$ genotypes among most of our patients lead us to conclude that these patients are incurred to different sources of infection at different times and this required an epidemiological evaluation of HBV infection among our patients not only in Wasit Province but also all over Iraq to control this abnormal acquisition of these genotypes by Iraqi people. Also, a clinical assessment and follow up of such patents is required. 


\section{References}

[1] Zainal IG, Safaa AA, Wajeeh KO. Biochemical parameters in relation to serum alphafetoprotein and leptin levels in Iraqi pateints with chronic liver diseases. Inter $\mathrm{J}$ life sci pharma res. 2013; 3(1): 16-22.

[2] Brown RS, McMahon BJ, Lok ASF, Wong JB, Ahmed TA, Mouchli MA, Wang Z, Prokop LJ, Murad MH, Mohammed K. Antiviral therapy in chronic hepatitis B viral infection during pregnancy: a systematic review and meta-analysis. J Hepatology. 2016; 63(1): 319-333.

[3] WHO Guidelines for the prevention, care and treatment of persons with chronic hepatitis B infection. Geneva, 2015; 27: $10-22$.

[4] Sunbul M. Hepatitis B virus genotypes: global distribution and clinical importance. World J Gastroenterology. 2014; 20(18): 5427-5434.

[5] Valsamakis A. Molecular testing in the diagnosis and management of chronic hepatitis B. Clin Microbiol Rev. 2007; 20(3): 426-439.

[6] Olinger CM, Lazouskaya NV, Eremin VF, Muller CP. Multiple genotypes and subtypes of hepatitis $\mathrm{B}$ and $\mathrm{C}$ viruses in Belarus: similarities with Russia and western European influences. Clin Microbiol Infect. 2008; 14(issue 6):575-581.

[7] Allain JP. Epidemiology of hepatitis B virus and genotype. J Clin Virol. 2006; 36 (Suppl 1): S12-S17.

[8] Mojiri A, Khadang B, Moaddeb A, Ghaedi M, Heidari T, Torab A, Salah A, Amirzadeh S, Jowkar Z, Mehrabani D, Amini-Bavil-Olyaee S, Behzad-Behbahani A, Dehyadegari M, Saberifirozi M, Ardabili M, Beheshti M, Rahsaz M, Banihashemi M, Azarpira N, Geramizadeh. B Hepatitis B virus genotypes in southwest Iran: molecular, serological and clinical outcomes. World J Gastroenterology. 2008; 14(10):1510-1513.

[9] Liu CJ, Kao JH. Global perspective on the natural history of chronic hepatitis B: role of hepatitis B virus genotypes A. J. Semin Liver Dis. 2013; 33(2):97-102.

[10] Mello FC, Melo MM, Martins RM, Gomes SA, Souto FJ, Nabuco LC, Villela-Nogueira CA, Coelho HS, Franz HC, Saraiva JC, Virgolino HA, Motta-Castro AR. Hepatitis B virus genotypes circulating in Brazil: molecular characterization of genotype F isolates. BMC Microbiol. 2007; 7(103): 1-9.

[11] Naito H, Hayashi S, Abe K. Rapid and specific genotyping system for hepatitis B virus corresponding to six major genotypes by PCR using type-specific primers. J Clin Microbiol. 2001; 39(1): 362-364.

[12] Baig S, Siddiqui AA, Ahmed W, Qureshi H, Arif A. The association of complex liver disorders with HBV genotypes prevalent in Pakistan. Virol J. 2007; 4(128): 1-7.

[13] Ross SM. Introduction to probability and statistics for Engineers and Scientists (4th edn.), Elsevier, London. 2009.

[14] Perrillo R, Richman D, Sherman K. Pocket guide to hepatitis B. University of Wisconsin Board of Regents and MDG Development Group. (2009): 1-63.

[15] Raimondo G, Allain JP, Brunetto MR, Buendia MA, Chen DS, Colombo M, Craxì A, Donato F, Ferrari C, Gaeta GB, Gerlich
WH, Levrero M, Locarnini S, Michalak T, Mondelli MU, Pawlotsky JM, Pollicino T, Prati D, Puoti M, Samuel D, Shouval D, Smedile A, Squadrito G, Trépo C, Villa E, Will H, Zanetti AR, Zoulim F. Statements from the Taormina expert meeting on occult hepatitis B virus infection. J Hepatology. 2008; 49(4): 652-657.

[16] AL-Hmudi AH. Virological and immunogenetic study of hepatitis B virus in patients of Basra Province-Iraq. Ph.D. thesis in Microbiology, College of Science, University of Basrah. 2011.

[17] Salim RW, Abdullah BA. The Prevalence of hepatitis B virus in high risk groups in Nineveh Governorate/ Iraq. J Baghdad Sci. 2014; 11(2): 888-893.

[18] Al-Aboudi SAK, Al-Hmudi HA. Some of immunogenetic status of HBsAg negative, $\mathrm{HBcAb}$ positive Blood donors in Basra Province-Iraq. Ann Biol Res. 2015; 6(4): 47-54.

[19] Khaled IAE, Mahmoud OM, Saleh AF, Baioumi EA. Prevalence of HBV genotypes in Egypt among hepatitis patients. J Ame Sci. 2010; 6(11): 185-190.

[20] Ghafourian S, Mohebi R, Khosravi A, Maleki A, Davoodian A, Sadeghifard N. Detection of hepatitis B virus DNA by Real-Time PCR in chronic hepatitis B patients, Ilam, Iran. Middle-East J Sci Res. 2011; 9 (4): 478-480.

[21] Weber B, Melchior W, Gehrke R, Doerr HW, Berger A, Rabenau H. Hepatitis B virus marker in anti $\mathrm{HBc}$ only positive individuals. J Med Virol. 2001; 64(3): 309-312.

[22] Keeffe EB, Dieterich DT, Han SHB, Jacobson IM, Martin P, Schiff ER, Tobias H, Wright TL. A Treatment algorithm for the management of chronic hepatitis B virus infection in the United States: an update. J Clin Gastroenterolgy Hepatology. 2006; 4(8): 936-962.

[23] Yim HJ, Lok AS. Natural history of chronic hepatitis B virus infection: what we knew in 1981 and what we know in 2005. J Hepatology. 2006; 43(2 Suppl 1): 173-181.

[24] Fattovich G, Bortolotti F, Donato F. Natural history of chronic hepatitis B: special emphasis on disease progression and prognostic factors. J Hepatology. 2008; 48(2): 335-352.

[25] McMahon BJ. The natural history of chronic hepatitis B virus infection. Hepatology. 2009; 49 (5): S45-S55.

[26] Gish RG, Given BD, Lai CL, Locarnini SA, Lau JY, Lewis DL, Schluep T. Chronic hepatitis B: virology, natural history, current management and a glimpse at future opportunities. J antiviral res. 2015; 121: 47-58.

[27] Bartholomeusz A, Schaefer S. Hepatitis B virus genotypes: comparison of genotyping methods. Rev Med Virol. 2004; 14 : $3-16$.

[28] Toan NL, Song LH, Kremsner PG, Duy DN, Binh VQ, Koeberlein B, Kaiser S, Kandolf R, Torresi J, Bock CT. Impact of the hepatitis B virus genotype and genotype mixtures on the course of liver disease in Vietnam. J Hepatology. 2006; 43(6): 1375-1384.

[29] Geramizadeh B, Kaboli R, Behzad-Behbahani A, Rahsaz M, Azarpira N, Aghdai M, Aytollahi M, Yaghoobi R, Baneehashemee M. A nested PCR method for the identification of hepatitis B virus genotype in paraffin blocks of formalin-fixed liver biopsies. Arch Iranian Med. 2008; 11(4): 455-458. 
[30] Rashid PMA, Salih GF. Identification and genotyping of hepatitis B virus by PCR assay using genotype specific primers. Europ Sci J. 2014; 10 (9): 424-433.

[31] Ahmed AM. Determination of hepatitis B virus genotypes among Iraqi chronic hepatitis B patients and inactive HBV carriers. Ph.D. Thesis, Genetic Engineering and Biotechnology Institute, Baghdad University, Iraq, 2013; pp. 195.

[32] Issa AH, Hamdan NA, Thwiny HT. Hepatitis B virus subclinical case infection in Basra patients discovered by preoperation of viral screening investigations. World J Pharm Res. 2015; 4(4): 1599-1610.

[33] Abdo AA, Al-Jarallah BM, Sanai FM, Hersi AS, Al-Swat K, Azzam NA, Al-Dukhayil M, Al-Maarik A, Al-Faleh FZ. Hepatitis B genotypes: relation to clinical outcome in patients with chronic hepatitis B in Saudi Arabia. World J Gastroenterology. 2006; 12(43): 7019-7024.

[34] Zekri AR, Hafez MM, Mohamed NI, Hassan ZK, El-Sayed MH, Khaled MM, Mansour T. Hepatitis B virus (HBV) genotypes in Egyptian pediatric cancer patients with acute and chronic active HBV infection. Virol J. 2007; 4(74): 1-7.

[35] Yoosefi K, Taheri M, Khosravi S, Saneie-Moghadam E, Mohagheghi-Fard AH. Genotyping of hepatitis B virus by multiplex PCR in Sistan and Baluchestan Province. Zahedan. J Res Med Sci. 2015); 15: 29-33.

[36] Chen B, Kao FJ, Liu CJ, Chen DS, Chen PJ. Genotypic dominance and novel recombinations in HBV genotype $\mathrm{B}$ and C coinfected intravenous drug users. J Med Virol. 2004; 73: 13-22.
[37] Mercier M, Laperche S, Girault A, Sureau C, Servant-Delmas A. Overestimation of incidence of hepatitis B virus mixedgenotype infections by use of the new line probe INNO-LiPA genotyping assay. J Clin Microbiol. 2011; 49(3). 1154-1156.

[38] Antaki N, Haffar S, Ali DS, Assaad F, Abou HR, Zeibane N, Nasserelddine M, Ibrahim N, Alhaj N, Jabbour E, Aaraj R, Antaki F, Kebbewar K. High prevalence of HBV genotype D in Syria and the clinical characteristics of hepatitis B e antigen-negative chronic hepatitis B. J Epidemiol Infect. 2010; 138(1): 40-44.

[39] Bozdayi G, Türkyilmaz AR, Idilman R, Karatayli E, Rota S, Yurdaydin C, Bozdayi AM. Complete genome sequence and phylogenetic analysis of hepatitis B virus isolated from Turkish patients with chronic HBV infection. J Med Virol. 2005; 76(4): 476-481.

[40] Yalcin K, Degertekin H, Bahcecioglu IH, Demir A, Aladag M, Yildirim B, Horasanli S, Ciftci S, Badur S. Hepatitis B virus genotype D prevails in patients with persistently elevated or normal ALT levels in Turkey. J Infect. 2004; 32(1). 24-29.

[41] Nie JJ, Sun KX, Li J, Wang J, Jin H, Wang L, Lu FM, Li T, Yan L, Yang JX, Sun MS, Zhuang H. A type-specific nested PCR assay established and applied for investigation of HBV genotype and subgenotype in Chinese patients with chronic HBV infection. Virolo J. 2012; 9(121): 1-9.

[42] Chen BF, Chen PJ, Jow GM, Sablon E, Liu CJ, Chen DS, Kao $\mathrm{JH}$. High prevalence of mixed genotype infections in hepatitis B virus infected intravenous drug users. J Med Virol. 2004; 74(4): 536-42. 